\title{
Improving the Ability to Memorize the Alphabet in Mild Intellectual Disability Student using the Letter Floor Puzzle
}

\author{
Gian Asri Septiany, Dina Istiqomah Rahayu, Whisqa Dayani \\ Departement of Special Need \\ Universitas Pendidikan Indonesia \\ Bandung, Indonesia \\ nha.isti14@gmail.com
}

\begin{abstract}
Intellectual disability is refers to an individual who have barriers receive and process information, so it requires a learning modification. Difficulties that are often found in intellectual disability children including lack of interest in learning, lack of motivation that affects the ability called memorization. To overcome these problems, learning media that can attract interest and learning abilities from intellectual disability students are required. These abilities can be developed optimally. The purpose of this study is to see the effectiveness of media puzzles, the basic foundation of the ability to read the alphabet to the intellectual disability student. This research is motivated by the existence of subjects who have not been able to recite all the alphabets at the grade 6 SDLB level. Years of studying at the school, he was only able to pronounce vowels. The interest in contrasting colors and the penchant for puzzles made the researchers take the initiative to apply it to the process of memorizing alphabets. The study used an experimental method with A-B-A design SSR method to see the effectiveness of letter floor puzzle media. The results showed an increase in the ability to memorize on the subject of the study. Based on the results of this study, it can be concluded that media puzzles can improve the ability to memorize the alphabet in mild intellectual disability students.
\end{abstract}

Keywords - intellectual disability; memorize the alphabet; letter floor puzzle media.

\section{INTRODUCTION}

Intellectual disability related to low intelligence development, including by Masland [1], namely that mental retardation in the condition of intellectual disability makes one unable to do what can be obtained in the cultural environment. Furthermore, Grossman intellectually disabled person as visually impaired on the public who are significant on average along with perfect behavioral errors and all that is realized during the development period [2]. Mental retardation refers to significantly subaverage general intellectual functioning resulting in or adaptive behavior and manifested during the developmental period [3].

Reading is one of the most important skills for children to study at school. But it is very difficult for children with intellectual disabilities [4]. Preliminary reading means the ability to recognize letters and the inscriptions of writing that emphasize the precise aspects of sounding the writing, reasonable pronunciation and intonation, smoothness and clarity of voice.

Teaching Preliminary reading on intellectually disabled children is not the same as children in general, because they will need a longer time to learn and are easily saturated when they begin to learn. Therefore the approach to preliminary reading learning must be packaged as attractive as possible, one of which with the use of learning media. Learning media that can support the initial reading process are letters floor puzzle.

The letter floor media will develop reasoning skills and also increase physical abilities for children. With the concept of learning while playing, children will step their feet on the letters to be taught. The child will be introduced to each letter based on his standing, and after this session ends the child is then asked to look for the letter mentioned. This study will try to ensure that the ability of the intellectually disabled child will be better when the learning motivation is improved through interactive games.

\section{METHOD}

The research method used in this study is an experimental method using the A-B-A single subject research (SSR) approach. The number of participants in this study was 1 child, aged 12 years. The current ability of children is to be able to pronounce and know consonants in alphabets (a, i, u, o), however it is said that abilities have not developed in the last 4 years.

Data collection techniques in this study are done through tests and observations. The test is a series of questions or exercises and tools used to measure knowledge skills and intelligence, abilities or talents that individuals or groups possess.

The test used in this study is a test with the form of student performance in reading the words that have been provided. This test has very large role to know students ability to pronounce, because the stimulus given in pointing and reciting a row of letters will require concentration in students. Data is collected at the time of the test carried out in the phase of beseline 1 (A1), treatment phase (B), and in the baseline phase 2 (A2). 
The use of the letter floor puzzle is used during the treatment phase, that is the child is asked to point letter, then step on the letter referred to by reciting the letter. This phase is intended to improve the ability to reason students in alphabetical letters.

\section{RESULT AND DISCUSSION}

A. Results

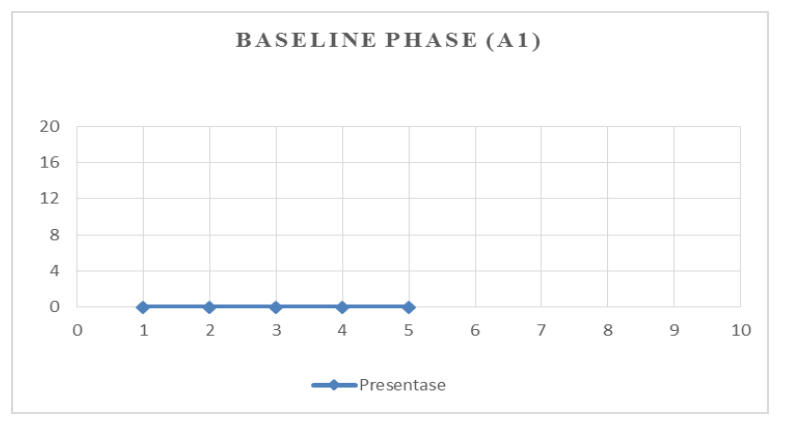

Fig. 1. Baseline Phase (A1)

Based on the graph above, it was found that the ability to pronounce letters on subjects at baseline conditions on a stable score at a percentage of $0 \%$.

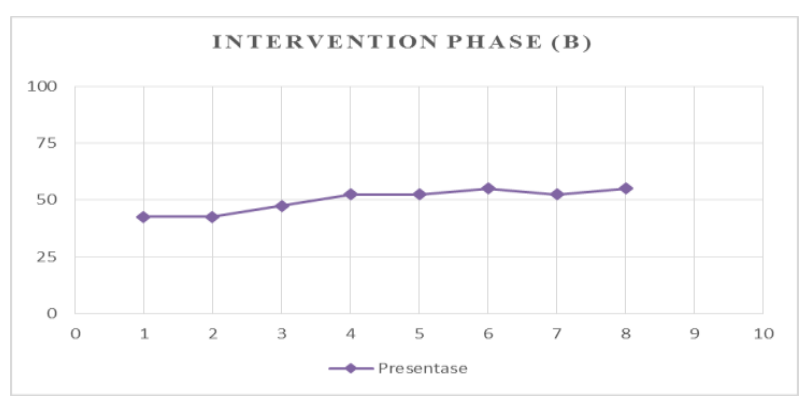

Fig. 2. Intervention Phase (B)

Furthermore, at the intervention stage, there appears to be an increase in the subject's ability. To see if there is a letter floor puzzle media influence after being given an intervention, then testing is done again.

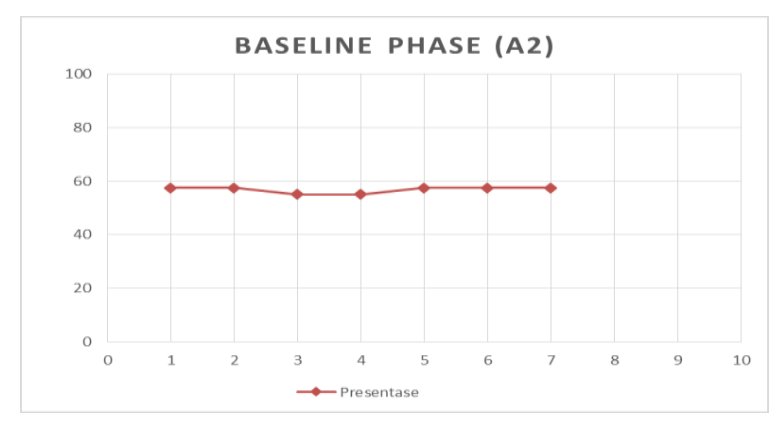

Fig. 3. Baselline Phase (A2)

The following is a composed chart of results that shows an increase from baseline-1 phase, intervention, and baseline- 2 .

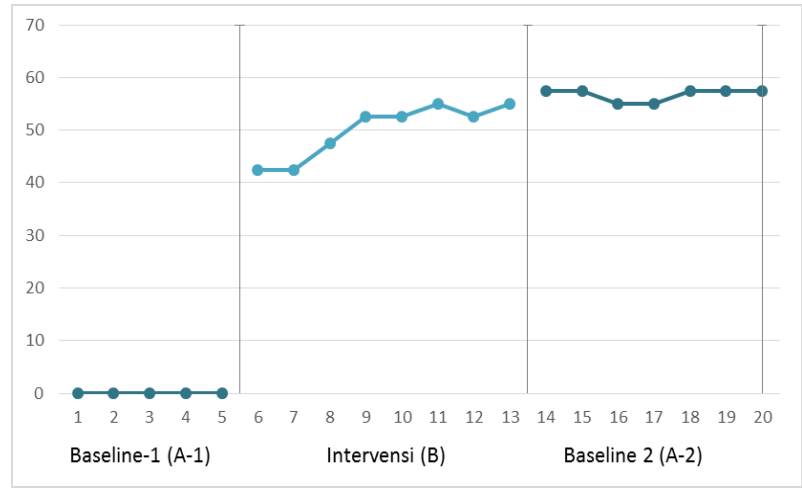

Fig. 4. Baseline-1 phase, intervention, and baseline-2

Overall learning outcomes obtained in baseline-1 (A-1), intervention (B), and baseline-2 (A-2) conditions can be concluded that there is an increase in the ability to pronounce letters in the subject of intellectually disabled in class VI SLB Cimahi.

\section{B. Discussion}

Intellectual disability is closely related to the problem of low intelligence development where intellectual function is below average, resulting in adaptive behavioral disorders that arise during development. Occurrence of limitations in intellectual function, subject will experience difficulties in solving a problem, capturing and maintaining information for a long time, learning from everyday experience until finally having difficulty generalizing knowledge from one field to another. Children with intellectual disabilities tend not to practice information because their ability to use short-term memory seems limited [5]. Short-term memory refers to the ability to remember information that has been stored for several seconds to several hours, such as step-by-step instructions given by the teacher to their students. Working memory refers to the ability to use information that has been maintained to carry out a task. Students with intellectual disabilities have disruptions in both types of memory, namely short-term memory and working memory. Such conditions require teachers to teach conceptual skills in accordance with the capacity of mentally disabled students.

Conceptual skills are skills that are more emphasized in the teaching and learning process in schools. The difficulty of children in processing information will be a big challenge when teaching reading, writing, and the concept of money. The first thing that is taught to students is reading, by reading they will be able to write and read nominal on sheets of money. Thus, reading is one of the most important skills for children to study at school. But it is very difficult for children with intellectual disabilities [4]. This difficulty was found in students who became subjects in this study, it was difficult to read words even though they had memorized the letters of the alphabet for years. The difficulty of the subject of connecting information into a new knowledge becomes a homework for educator. The difficulty of the subject means that he is still at the beginning of the reading stage, he already knows the letters, suggests the letters correctly, just cannot combine the letters into a word. 
Preliminary reading is one of the most important teachings for every child to learn, including intellectually disabled children. One of the effects of intellectual disability is cognitive development, where this aspect is very important role in learning ability. Learning abilities include reading ability which is the basis for a child in mastering the next field of study. Teaching students with intellectual barriers to read is very challenging [6]. These students face severe deficits in memory and language which make it very difficult for them to learn to read. Furthermore, behavioral problems can interfere with their learning. While there are many examples of intellectually disabled students who succeed in learning to read, most students with intellectual disabilities learn very little, if any, basic reading skills. In fact, only 1 in 5 students with an ID attain even minimal literacy skills [7].

There are two stages in reading activities, namely preliminary and further reading. Preliminary reading emphasizes the conditioning of students to enter and recognize reading material [8]. In preliminary reading, the learning taught is done in an integrated manner, and focuses on the recognition of letters and words, then connects them to sounds.

Teaching Preliminary reading on intellectually disabled children is not the same as children in general, because they will need a longer time to learn and are easily saturated when begin to learn. Therefore the approach to preliminary reading learning must be carried out as attractive as possible, one of which is the use of learning media. Learning media can refer to the preferences/hobbies of the students themselves, so that it will trigger the spirit of learning in intellectually disabled students.

Based on the data that has been obtained in the field, the results of data analysis are presented in the form of line graphs using the SSR method (single subject research) design of A-BA which was conducted in 20 sessions. In the baseline-1 (A-1) phase which was carried out as many as 5 sessions, the subject's ability did not show any change, with the acquisition of a score of 0 out of the 40 maximum scores. Then in the intervention phase (B) which was carried out as many as 8 sessions, the subject experienced an increase with the highest score of 23 from a maximum score of 40 , and in the baseline phase-2 (A-2) it was seen that the effect was not much different from the intervention stage, where the subject obtained a score. The highest is 23 out of the maximum score available. The result clearly shows that there is a positive influence with the use of the letter floor puzzle media that is based on the media that the child felt engaged before.

More clearly the results of this study illustrate that there has been an increase in the mean level of each phase condition obtained by the subject as follows, in baseline-1 (A-1) conditions the mean level obtained is equal to $0 \%$. In the intervention phase condition (B) the mean level obtained is equal to $50 \%$, and in the baseline phase condition 2 (A-2) the mean level obtained is $56.8 \%$. So, if the conclusions drawn at baseline-1 (A-1) to the baseline-2 (A-2) phase conditions increase by $56.8 \%$.

Overall learning outcomes obtained in baseline-1 (A-1), intervention (B), and baseline-2 (A-2) conditions can be concluded that there is an increase in the ability to pronounce letters on the subject of intellectual disability in class VI SLBN Cimahi. Thus, the use of learning media using letter floor puzzle is proven to improve the learning process, as Kemp and Dayon argued [9]. One of the contributions of learning media is learning can be more interesting, the quality of learning can be improved, the learning process can take place anytime and anywhere, and students' positive attitudes towards learning materials and learning processes can be improved.

Teaching students with intellectual barriers to read is very challenging [6]. The teaching challenge has been proven in this study, where the learning process will be effective if the learning resources of students are derived from the students' own preferences. Although the study showed a significant increase in the preliminary reading ability in the form of reciting letters, the results obtained have not been fully able to conclude whether the use of the letter floor puzzle media really can improve the ability to pronounce letters on the subject. Further research is needed whether the subject increases due to understanding caused by the media or due to repeated use of letters.

\section{CONCLUSION}

Although the study showed a significant increase in the preliminary reading ability in the form of reciting letters, the results obtained have not been fully able to conclude whether the use of the letter floor puzzle media really can improve the ability to pronounce letters on the subject. Further research is needed whether the subject increases due to understanding caused by the media or due to repeated use of letters.

\section{REFERENCES}

[1] J. H. Rothstein, Mental retardation: readings and resources, New York : Holt, Rinehart, Winston, 1971.

[2] D. P. Hallahan, and J. M. Kauffan, Exceptional children, USA: Prentice Hall, Englewood Cliffs, 1988.

[3] R. L. Schalock, S. A. Borthwick-Duffy, V. J. Bradley, W. H. Buntinx, D. L. Coulter, E. M. Craig and K. A. Shogren, Intellectual disability: definition, classification, and systems of supports, Washington: American Association on Intellectual and Developmental Disabilities, 2010.

[4] F. A. Conners, C. J. Rosenquist, A. C. Sligh, J. A. Atwell, and T. Kiser,). "Phonological reading skills acquisition by children with mental retardation," Research in Developmental Disabilities, vol 27, no 2, pp.121-137, 2006.

[5] S. Kirk, J. J. Gallagher, M. R. Coleman, and N. Anastasiow, Educating exceptional children 12th edition, New York: Houghton Miffl in Harcourt Publishing Company, 2009.

[6] J. H. Allor, P. G. Mathes, J. K. Roberts, J. P. Cheatham and T. M. Champlin, "Comprehensive reading instruction for students with intellectual disabilities: findings from the first three years of a longitudinal study,". Psychology in the Schools, pp.445-466. 2010.

[7] D. S. Katims, "Literacy assessment of students with mental retardation: an exploratory investigation," Education and Training in Mental Retardation and Developmental Disabilities, vol 36, pp.363-371, 2001.

[8] P. M. Sareb, Menumbuhkan minat baca sejak dini, Jakarta: P.T. Indeks, 2008.

[9] R. Susilana, and C. Riyana, Media pembelajaran: hakikat, pengembangan, pemanfaatan, dan penilaian, Bandung: CV Wacana Prima, 2009. 